\title{
SS-018＼cjkstart宗教心理学的研究の展開一現代社会における「宗教の役割」を 考える一
}

\author{
企画代表者: 中尾 将大 (大阪大谷大学) \\ 企画者: 松島 公望 (東京大学) \\ 話題提供者: 平子 泰弘\#（曹洞宗総合研究センター） \\ 話題提供者: 西脇良 (南山大学) \\ 話題提供者：酒井 克也\#（出雲大社和貴講社） \\ 指定討論者：中尾 将大 (大阪大谷大学) \\ 指定討論者: 荒川歩 (武蔵野美術大学) \\ 司会者：松島 公望（東京大学）
}

日本心理学会第76回大会において，宗教心理に関する企画が多く開催された。大会最終日にも拘らず, 多くの方が参加していた。これは，「宗教」という事象が少なくとも心理学において関心を集めている ことを反映していると考える。現代社会において宗教が人間の心理に与える影響は依然，大きいのだろ う。現代人にとって宗教とは何か。科学文明の恩恵の元にある現代人がなお，宗教に求めているものが あれば，それは何か。この点を議論することは人間が宗教を求める心理や現代社会における宗教の役割 を考察することにつながる。本WSでは, 我が国でなじみが深いと思われる仏教, キリスト教, 日本神 道に属される宗教者の先生方に「宗教の役割」についての持論をご発表いただく。そして，指定討論は 心理学拉よび宗教学の立場からコメントをいただく。宗教学と心理学の視点から宗教を眺め, 現代社会 におけるその役割と影響について議論をすることを目的とする。

\section{平子 泰弘（曹洞宗総合研究センター）}

近年, マスコミでは宗教離れ，殊に仏教離れの現象が見られることが取り上げられる。葬式不要論も語られるなかで, 震 災を契機に宗教に対する見方や要望に変化が感じられる。これまで葬式仏教と表現され，その形骸化がみられるなかで，亡 き人を市い偲び祈っていく葬儀や供養のもつ根本的な機能に気付いてきているのではないだらうか。あるいは,カウンセラー ではフォローできない心の問題を宗教者が埋められるのではないかと考える。

\section{西脇 良（南山大学）}

日本社会に拀いてキリスト教の存在が感じられる場の一つに, 学校教育があるだろう。そこで, 現代社会におけるキリス 卜教の役割を検討するため, ミッション・スクール，とくにカトリック学校を取り上げる。まず日本におけるカトリック教 育の歴史，現状掞よび課題を概観し，次に報告者が関わる中部地方のカトリック小学校での教育実践を報告する。最後に， 一カトリック司祭としての立場からの私論・試論を添えてみたい。

\section{酒井 克也（出雲大社和貴講社）}

神社との関わり, 地域や家庭内での祭祀など制度的な意味での神道は, 戦後の流動化した生活形態と共に急速に衰退した と指摘されている。その後に残ったものは, 生活や思考の土台となる「支配的言説」として語られる神道的思想ではなかろ うか。その根源は, 海に閉ざされた，しかし大自然の恩恵に満ちた島国という環境で共生を図った先人の智慧にあろう。地 球という環境が「狭く」なった今こそ，その智慧は大きな価値を持つと考える。 